\title{
EFFECT OF MICROWAVE IRRADIATION ON THE SOLUTION OF AMINO ACID CHROMIUM COMPLEXES
}

\author{
Sujun WANG ${ }^{1}$, Wuyong CHEN ${ }^{1,2}$, Luming YANG ${ }^{*}{ }^{1,2}$, Jinwei ZHANG ${ }^{1,2 *}$ \\ ${ }^{1}$ Key Laboratory of Leather Chemistry and Engineering of the Ministry of Education, Sichuan University, Chengdu, 610065, P. \\ R. China \\ ${ }^{2}$ National Engineering Laboratory for Clean Technology of Leather Manufacture, Sichuan University, Chengdu 610065, P. R. \\ China
}

Received: 04.12.2019

Accepted: 16.03 .2020

https://doi.org/10.24264/Ifj.20.1.5

\section{EFFECT OF MICROWAVE IRRADIATION ON THE SOLUTION OF AMINO ACID CHROMIUM COMPLEXES}

ABSTRACT. In recent years, microwave technology has been applied more and more in tanning, however there is still a lack of research on the effect of microwave irradiation on the interaction between chromium complex and amino acids. In the study, the influences of microwave irradiation on the reactions were studied by selecting four kinds of characteristic amino acids in collagen, aspartic acid, hydroxyproline, lysine and glycine, to provide new knowledge on tanning process. The solution of chromium complex reacted with amino acid was heated by microwave as a sample and by water bath heating under the same conditions as a control. During the process, the pH variation and UV-Visible absorption spectrum were used to determine the influence of microwave on the reaction between amino acids and chromium complex. The results demonstrated that both microwave irradiation and water bath could accelerate the reaction rate and promote the stability of the amino acid chromium complex. However, the microwave irradiation had much more obvious effects on these changes than the water bath, indicating that microwave irradiation could promote the reaction between amino acid and chromium complex further and make the formed amino acid chromium complex more stable. In addition, microwave had stronger effect on improving the reaction when the polarity of amino acid was larger. In short, this study would provide some hints for understanding how microwave affects chrome tanning and might be useful to apply microwave in tanning in future.

KEY WORDS: microwave, amino acid, chromium complex, complex stability

EFECTUL IRADIERII CU MICROUNDE ASUPRA SOLUTIEI DE COMPLECȘI DE CROM ȘI AMINOACIZI

REZUMAT. În ultimii ani, tehnologia cu microunde a fost aplicată tot mai mult la tăbăcirea pieilor; cu toate acestea, încă există lacune privind cercetarea efectului iradierii cu microunde asupra interacțiunii dintre complexul de crom și aminoacizi. În acest studiu s-a examinat efectul iradierii cu microunde asupra reacțiilor prin selectarea a patru tipuri de aminoacizi caracteristici colagenului: acid aspartic, hidroxiprolină, lizină și glicină, pentru a oferi noi cunoștințe cu privire la procesul de tăbăcire. O probă din soluția complexului de crom reacționat cu aminoacid a fost încălzită la microunde și încălzită în baie de apă în aceleași condiții ca proba martor. În timpul procesului, s-au utilizat variația pH-ului și spectrul de absorbție UV-Vis pentru a determina influența microundelor asupra reacției dintre aminoacizi și complexul de crom. Rezultatele au demonstrat că atât iradierea cu microunde, cât și baia de apă ar putea accelera viteza de reacție și promova stabilitatea complexului de crom şi aminoacizi. Cu toate acestea, iradierea cu microunde a avut efecte mult mai evidente asupra acestor modificări decât baia de apă, ceea ce indică faptul că iradierea cu microunde ar putea promova reacția dintre aminoacid și complexul de crom și poate face complexul de crom și aminoacizi mai stabil. În plus, microundele au avut un efect mai puternic asupra îmbunătățirii reacției atunci când polaritatea aminoacidului a fost mai mare. Pe scurt, acest studiu oferă câteva indicii pentru înțelegerea modului în care microundele afectează tăbăcirea în crom și ar putea fi util pentru aplicarea microundelor în procesul de tăbăcire în viitor.

CUVINTE CHEIE: microunde, aminoacizi, complex de crom, stabilitatea complecșilor

EFFET DE L'IRRADIATION DES MICRO-ONDES SUR LA SOLUTION DES COMPLEXES DE CHROME ET D'ACIDES AMINÉS

ABSTRAIT. Ces dernières années, la technologie des micro-ondes a été de plus en plus appliquée au tannage, mais il y a encore des lacunes dans l'étude de l'effet de l'irradiation aux micro-ondes sur l'interaction entre le complexe de chrome et les acides aminés. Dans l'étude, les influences de l'irradiation aux micro-ondes sur les réactions ont été étudiées en sélectionnant quatre types d'acides aminés caractéristiques du collagène : l'acide aspartique, l'hydroxyproline, la lysine et la glycine, pour fournir de nouvelles connaissances sur le processus de tannage. Un échantillon de la solution de complexe de chrome ayant réagi avec un acide aminé, a été chauffée par micro-ondes et par chauffage au bainmarie dans les mêmes conditions qu un échantillon de contrôle. Au cours du processus, la variation du pH et le spectre d'absorption UV-Visible ont été utilisés pour déterminer l'influence des micro-ondes sur la réaction entre les acides aminés et le complexe de chrome. Les résultats ont démontré que l'irradiation aux micro-ondes et le bain-marie pouvaient accélérer la vitesse de réaction et favoriser la stabilité du complexe de chrome d'acide aminé. Cependant, l'irradiation aux micro-ondes a eu des effets beaucoup plus évidents sur ces changements que le bainmarie, indiquant que l'irradiation aux micro-ondes peut favoriser davantage la réaction entre l'acide aminé et le complexe de chrome et peut rendre le complexe de chrome d'acide aminé formé plus stable. De plus, les micro-ondes ont eu un effet plus fort sur l'amélioration de la réaction lorsque la polarité des acides aminés était plus grande. En bref, cette étude fournit quelques conseils pour comprendre comment les micro-ondes affectent le tannage au chrome et peut être utile d'appliquer les micro-ondes dans le tannage à l'avenir. MOTS CLÉS: micro-ondes, acide aminé, complexe de chrome, stabilité du complexe

\footnotetext{
"Correspondence to: Luming YANG and Jinwei ZHANG, Key Laboratory of Leather Chemistry and Engineering of the Ministry of Education, Sichuan University, Chengdu, 610065, P. R. China, emails: ylmI11982@126.com, scutanner@163.com
} 


\section{INTRODUCTION}

Microwave is an electromagnetic wave with frequency range from $300 \mathrm{MHz}$ to 300 $\mathrm{GHz}$ and could act on polar molecules directly, and then causing dipole turning to polarization and interfacial polarization to heat materials. Microwave irradiation has advantages of uniform, selective, energy-efficient and no hysteresis compared with traditional heating methods [1]. It excites the transition of the rotational energy level of the molecule, increases the energy of the molecule and reduces the activation energy of chemical reactions; consequently, some reactions may occur under gentle condition rather than extreme situations [2]. Also, microwave radiation accelerates the rate of chemical reactions [3] and promotes the yield of organic reactions $[4,5]$.

Hitherto, microwave irradiation had been applied in many tanning processes for improving leather quality. The shrinkage temperature and tear strength of chrome tanned leather could be improved as well as chrome tanning would be finished under lower terminal $\mathrm{pH}[6,7]$. Microwave had been used to improve tanning agent exhaustion and made products have better thermal stability in aluminium tanning, zirconium tanning and vegetable tanning [8-10]. Besides, the combination between collagen and chemicals could be strengthened during other leather manufacturing processes. The colour fastness of leather could be enhanced when microwave was used in a new dyeing method to fix the dyestuff [11]. Leather softness was improved under microwave drying due to less migration of oil but better uniform distribution [12-15].

Microwave irradiation, as a new technology to increase degree and rate of chemical reactions, might promote the formation of metal complexes. The current researches showed that microwave irradiation could further promote the hydrolysis and olation reaction of chromium tanning solutions compared with water bath [16, 17]. Moreover, microwave irradiation accelerated the reaction rate and improved the stability of chromium complexes in the complexation of carboxylic acids with chromium $[18,19]$.

The basis mechanism of tanning is the complexation reaction between amino acids and chromium. As a basic structural unit of protein, the amino acid can be used as simplest protein mimicry to study the tanning process for overcoming the impact of the permeation of tanning agent into pelt. The homogeneous reaction is also easier to analyse $[20,21]$. Amino acids can be classified into non-polar, polar uncharged, positively charged (basic) and negatively charged (acidic) based on the polarity of the R groups of the amino acid (Figure 1) [22].<smiles>[R]C(N)C(=O)O</smiles>

Figure 1. The schematic diagram of amino acid structure

In the study, four kinds of characteristic amino acids in collagen, aspartic acid, hydroxyproline, lysine and glycine, were selected as starting materials to react with chromium. Among them, aspartic acid is an acidic amino acid, lysine is a basic amino acid, glycine is the most abundant amino acid in collagen, and hydroxyproline is the characteristic amino acid of collagen. Microwave was used to heat the reaction between the four kinds of representative amino acids and chromium nitrate; meanwhile, the reactions heated by water bath at same condition were used as control. For keeping consistent with the chrome tanning process, the temperature was $40^{\circ} \mathrm{C}$ and $\mathrm{pH}$ was 4.0 when the amino acids were reacted with chromium nitrate. The results in the study would be a reference for applying microwave in chrome tanning.

\section{EXPERIMENTAL}

\section{Materials}

Concentrated perchloric acid, sodium bicarbonate, chromium nitrate, lysine, glycine, aspartic acid, and hydroxyproline were analytical grade agents from Chengdu Kelong Chemical Ltd.

\section{Experimental Solutions}

$0.1 \mathrm{~mol} / \mathrm{L}$ chromium nitrate solution, lysine solution, glycine solution, hydroxyproline solution and $0.05 \mathrm{~mol} / \mathrm{L}$ aspartic acid solution were prepared in advance. $2.8 \%(\mathrm{w} / \mathrm{v})$ dilute perchloric acid solution was prepared as solvent 
for subsequent reactions and $0.5 \%(\mathrm{w} / \mathrm{v})$ sodium bicarbonate solution was used for adjusting solution $\mathrm{pH}$.

The amino acid chromium complex solution was prepared by the molar ratio of amino acid to chromium nitrate solution is $3: 2$. The $\mathrm{pH}$ of the amino acid chromium complex solution was adjusted to 4.0 sodium bicarbonate solution with and then left for 1 hour.

\section{Amino Acid Chromium Complex Solutions Heated for Different Times}

$50 \mathrm{~mL}$ of the amino acid chromium complex solution was put into a $100 \mathrm{~mL}$ beaker and then heated with an MCR-3C microwave reactor (Xi'an Yuhui instrument Ltd. the frequency of microwave was $2450 \mathrm{MHz}$,) at $40^{\circ} \mathrm{C}$ for, 5,15 , 30, 60, 120 and 240 min with stirring. A DF-101S water bath heater (Wuhan Keíer instrument Company) was used to heat control samples at same conditions. The $\mathrm{pH}$ meter and UV-Vis spectrometer were used to measure changes the solutions when they cooled down to room temperature.

\section{pH Measurement}

$\mathrm{pH}$ standard solutions were used to calibrate the $\mathrm{PH}-3 \mathrm{C}$ pH meter (Shanghai Yidian Science Instrument Company), then the $\mathrm{pH}$ of the amino acid chromium complex solutions was measured at room temperature, the final result was average of three tests.

Based on the measured $\mathrm{pH}$, the reaction rate of amino acid chromium complex was calculated as following equation [23]:

$$
r=\frac{d c}{v d t}=\frac{\Delta c_{H^{+}}}{\Delta t}
$$

where: $r=$ reaction rate, it represents the increasing concentration of product in unit time. $\Delta \mathrm{c}_{\mathrm{H}}{ }^{+}$is the change of $\mathrm{H}^{+}$concentration and $\Delta \mathrm{t}$ is the reaction time. $\Delta \mathrm{c}_{\mathrm{H}}{ }^{+}=10^{-\Delta \mathrm{pH}}$.

\section{UV-Vis Spectrum Measurement}

A UV1900 UV-Vis spectrometer (Shanghai Jinghua Instrument Co.) was used to scan the amino acid chromium complex solution from 350 to $650 \mathrm{~nm}$ with a scanning rate of $600 \mathrm{~nm} /$ min and wavelength (WL) interval of $1 \mathrm{~nm}$. The wavelength of amino acid chromium complex solution at about $420 \mathrm{~nm}$ was named $\lambda_{1}$, and the corresponding absorbance was named $A_{1}$. The wavelength of amino acid chromium complex solution at about $580 \mathrm{~nm}$ was named $\lambda_{2}$, and the corresponding absorbance was named $A_{2}$. The R-value was calculated using the following equation [24]:

$$
R=\frac{A_{1}}{A_{2}}
$$

\section{RESULTS AND DISCUSSION}

\section{The Influence of Microwave Irradiation on UV-Vis Absorption of Amino Acid Chromium Complex}

The absorption peaks and $R$ values of the ultraviolet-visible spectrum of four kinds of amino acids reacted with chromium under different conditions are shown from Table 1 to Table 4.

Table 1: The changes of lysine chromium complex UV-Vis absorption peak and R value

\begin{tabular}{cccccccc}
\hline & \multicolumn{3}{c}{ Water bath } & \multicolumn{5}{c}{ Microwave } \\
Time (min) & $\lambda_{\max 1}(\mathrm{~nm})$ & $\lambda_{\max 2}(\mathrm{~nm})$ & $\mathrm{R}$ & $\lambda_{\max 1}(\mathrm{~nm})$ & $\lambda_{\operatorname{max2}}(\mathrm{nm})$ & $\mathrm{R}$ \\
\hline 0 & 415 & 568 & 1.18 & 415 & 568 & 1.18 \\
5 & 415 & 568 & 1.18 & 415 & 568 & 1.18 \\
15 & 415 & 568 & 1.18 & 415 & 568 & 1.18 \\
30 & 415 & 568 & 1.18 & 415 & 568 & 1.18 \\
60 & 414 & 567 & 1.18 & 414 & 567 & 1.17 \\
120 & 414 & 567 & 1.18 & 414 & 565 & 1.17 \\
240 & 413 & 566 & 1.18 & 413 & 565 & 1.17 \\
\hline
\end{tabular}


Table 2: The changes of glycine chromium complex UV-Vis absorption peak and R value

\begin{tabular}{ccccccc}
\hline Time & \multicolumn{3}{c}{ Water bath } & \multicolumn{5}{c}{ Microwave } \\
$(\min )$ & $\lambda_{\max 1}(\mathrm{~nm})$ & $\lambda_{\max 2}(\mathrm{~nm})$ & $\mathrm{R}$ & $\lambda_{\max 1}(\mathrm{~nm})$ & $\lambda_{\max 2}(\mathrm{~nm})$ & $\mathrm{R}$ \\
\hline 0 & 408 & 546 & 0.93 & 408 & 546 & 0.93 \\
5 & 408 & 547 & 0.93 & 408 & 546 & 0.93 \\
15 & 408 & 546 & 0.93 & 408 & 547 & 0.92 \\
30 & 407 & 547 & 0.92 & 407 & 547 & 0.92 \\
60 & 407 & 547 & 0.92 & 408 & 554 & 0.92 \\
120 & 407 & 547 & 0.92 & 407 & 547 & 0.92 \\
240 & 407 & 547 & 0.92 & 407 & 547 & 0.92 \\
\hline
\end{tabular}

Table 3: The changes of aspartic acid chromium complex UV-Vis absorption peak and R value

\begin{tabular}{ccccccc}
\hline \multirow{2}{*}{ Time (min) } & \multicolumn{3}{c}{ Water bath } & \multicolumn{4}{c}{ Microwave } \\
& $\lambda_{\text {max }}(\mathrm{nm})$ & $\lambda_{\text {max }}(\mathrm{nm})$ & $\mathrm{R}$ & $\lambda_{\max 1}(\mathrm{~nm})$ & $\lambda_{\max 2}(\mathrm{~nm})$ & $\mathrm{R}$ \\
\hline 0 & 411 & 567 & 0.93 & 411 & 567 & 0.93 \\
5 & 411 & 566 & 0.92 & 411 & 565 & 0.90 \\
15 & 410 & 564 & 0.89 & 410 & 562 & 0.87 \\
30 & 409 & 561 & 0.86 & 409 & 560 & 0.85 \\
60 & 408 & 558 & 0.82 & 408 & 557 & 0.81 \\
120 & 407 & 555 & 0.79 & 407 & 554 & 0.78 \\
240 & 406 & 553 & 0.76 & 405 & 551 & 0.75 \\
\hline
\end{tabular}

Table 4: The changes of hydroxyproline chromium complex UV-Vis absorption peak and R value

\begin{tabular}{ccccccc}
\hline \multirow{2}{*}{ Time (min) } & \multicolumn{3}{c}{ Water bath } & \multicolumn{4}{c}{ Microwave } \\
& $\lambda_{\text {max } 1}(\mathrm{~nm})$ & $\lambda_{\text {max } 2}(\mathrm{~nm})$ & $\mathrm{R}$ & $\lambda_{\text {max } 1}(\mathrm{~nm})$ & $\lambda_{\text {max } 2}(\mathrm{~nm})$ & $\mathrm{R}$ \\
\hline 0 & 411 & 558 & 1.08 & 411 & 558 & 1.08 \\
5 & 411 & 558 & 1.08 & 411 & 558 & 1.08 \\
15 & 411 & 557 & 1.07 & 410 & 557 & 1.07 \\
30 & 410 & 557 & 1.06 & 410 & 556 & 1.06 \\
60 & 409 & 555 & 1.04 & 408 & 554 & 1.02 \\
120 & 409 & 554 & 1.03 & 408 & 553 & 1.02 \\
240 & 408 & 553 & 1.01 & 407 & 552 & 1.01 \\
\hline
\end{tabular}

The violet shift of the absorption peaks relates to coordination reaction rate between chromium complex and ligands. Generally, larger violet shift means faster reaction rate and greater reaction degree.

As shown in Table 1 to Table 4, the wavelength at about $580 \mathrm{~nm}$ decreases and violet shift of the chromium complex reacted with the amino acid is obvious with time prolonging, indicating the coordination reaction rate is faster and the reaction degree is more thorough with the warming time increasing. Under the same conditions, the violet shift of the microwave samples is 1-3 $\mathrm{nm}$ larger than the control samples, indicating that the effect of microwave irradiation on promoting the rate and degree of complexation between amino acid and chromium is more significant than water bath. 
This additional promoting effect comes from the special effect that microwave irradiation could act on the polar substances directly during reaction to generate more complicated movements and drastic collisions for chromium complexes and amino acid.

It can be seen that the $R$ value of microwave irradiation sample and water bath control sample both decrease during heating process, and $R$ value of all samples is less than 1.19 at any time, showing microwave effect on the complexation between amino acids and chromium might not alter the binding pattern between chromium and amino acids.

Compared with the changes of violet shift and $R$ value of chromium complexes reacted with different amino acids under microwave irradiation and water bath heating, it could be found that aspartic acid results in the most obvious change while glycine leads to the least. The changing tendency from large to small is aspartic acid > hydroxyproline > lysine > glycine. The polarity of these four kinds of amino acids is different because of distinctive $R$ group. The $R$ group of aspartic acid, hydroxyproline, lysine and glycine contain carboxyl, hydroxyl, amino with long aliphatic chain and hydrogen respectively. It is clear that the amino acids with higher polarity bring about smaller $\mathrm{R}$ value of chromium complex, indicating microwave affecting the reaction between chromium and amino acid significantly when the polarity of the ligand is larger.

\section{The Influence of Microwave Irradiation on pH Change of Amino Acid Chromium Complex}

The $\mathrm{pH}$ changes of different amino acids with chromium are shown from Table 5 to Table 8.

Table 5: The $\mathrm{pH}$ change and reaction rate of lysine-chromium nitrate reaction

\begin{tabular}{ccccc}
\hline \multirow{2}{*}{ Time: $\min$} & \multicolumn{2}{c}{$\mathrm{pH}$} & \multicolumn{3}{c}{ Reaction rate: $10^{-7} \mathrm{~mol} /(\mathrm{L} \cdot \mathrm{min})$} \\
& Microwave & Water bath & Microwave & Water bath \\
\hline 0 & 3.93 & 3.93 & 0 & 0 \\
5 & 3.87 & 3.89 & 34.81 & 22.60 \\
15 & 3.85 & 3.85 & 15.80 & 15.80 \\
30 & 3.82 & 3.82 & 11.30 & 11.30 \\
60 & 3.74 & 3.78 & 10.70 & 8.070 \\
120 & 3.67 & 3.73 & 8.025 & 5.725 \\
240 & 3.53 & 3.65 & 7.401 & 4.429 \\
\hline
\end{tabular}

Table 6: The $\mathrm{pH}$ change and reaction rate of glycine-chromium nitrate reaction

\begin{tabular}{ccccc}
\hline \multirow{2}{*}{ Time: $\min$} & \multicolumn{2}{c}{$\mathrm{pH}$} & \multicolumn{2}{c}{ Reaction rate: $10^{-7} \mathrm{~mol} /(\mathrm{L} \cdot \mathrm{min})$} \\
& Microwave & Water bath & Microwave & Water bath \\
\hline 0 & 4.00 & 4.00 & 0 & 0 \\
5 & 3.78 & 3.78 & 132.0 & 132.0 \\
15 & 3.74 & 3.76 & 54.67 & 49.20 \\
30 & 3.68 & 3.72 & 36.30 & 30.17 \\
60 & 3.64 & 3.67 & 21.51 & 18.97 \\
120 & 3.54 & 3.65 & 15.70 & 9.492 \\
240 & 3.52 & 3.64 & 8.427 & 5.379 \\
\hline
\end{tabular}


Table 7: The $\mathrm{pH}$ change and reaction rate of aspartic acid-chromium nitrate reaction

\begin{tabular}{ccccc}
\hline \multirow{2}{*}{ Time: min } & \multicolumn{2}{c}{$\mathrm{pH}$} & \multicolumn{2}{c}{ Reaction rate: $10^{-7} \mathrm{~mol} /(\mathrm{L} \cdot \mathrm{min})$} \\
& Microwave & Water bath & Microwave & Water bath \\
\hline 0 & 3.89 & 3.89 & 0 & 0 \\
5 & 3.83 & 3.85 & 38.17 & 24.80 \\
15 & 3.72 & 3.74 & 41.13 & 35.47 \\
30 & 3.62 & 3.66 & 37.03 & 30.00 \\
60 & 3.48 & 3.55 & 32.05 & 25.50 \\
120 & 3.38 & 3.43 & 24.01 & 20.23 \\
240 & 3.26 & 3.34 & 17.53 & 13.68 \\
\hline
\end{tabular}

Table 8: The $\mathrm{pH}$ change and reaction rate of hydroxyproline-chromium nitrate reaction

\begin{tabular}{ccccc}
\hline Time: & \multicolumn{2}{c}{$\mathrm{pH}$} & \multicolumn{2}{c}{ Reaction rate: $10^{-7} \mathrm{~mol} /(\mathrm{L} \cdot \mathrm{min})$} \\
min & Microwave & Water bath & Microwave & Water bath \\
\hline 0 & 3.90 & 3.90 & 0 & 0 \\
5 & 3.72 & 3.72 & 129.2 & 129.2 \\
15 & 3.67 & 3.69 & 58.60 & 52.20 \\
30 & 3.62 & 3.66 & 38.00 & 30.97 \\
60 & 3.49 & 3.57 & 32.95 & 23.88 \\
120 & 3.39 & 3.50 & 23.46 & 15.86 \\
240 & 3.34 & 3.46 & 13.80 & 9.200 \\
\hline
\end{tabular}

Table 5 to Table 8 show that both microwave irradiation and water bath heating affect the $\mathrm{pH}$ and rate of the reaction between amino acid and chromium complex. In the microwave experiment, the $\mathrm{pH}$ values decrease by 0.48 for glycine, 0.56 for hydroxyproline, 0.63 for aspartic acid and 0.40 for lysine, respectively from beginning to $240 \mathrm{~min}$, while the changes of control are $0.36,0.44,0.55$ and 0.28 for corresponding samples. Based on the data of $\Delta$ $\mathrm{pH}$, the reaction rates can be calculated and the reaction rates between microwave and water bath are compared. The reaction rates between amino acids and chromium under microwave irradiation are faster compared to the control under any corresponding condition.

According to the formula: $\left[\mathrm{Cr}\left(\mathrm{H}_{2} \mathrm{O}\right)_{6}\right]^{3+} \rightarrow$ $\left[\mathrm{Cr}(\mathrm{OH})\left(\mathrm{H}_{2} \mathrm{O}\right)_{5}\right]^{2+}+\mathrm{H}^{+}$and $\left[\mathrm{Cr}\left(\mathrm{H}_{2} \mathrm{O}\right)_{6}\right]^{3+}+\mathrm{RCOOH}$ $\rightarrow\left[\mathrm{Cr}(\mathrm{RCOO})\left(\mathrm{H}_{2} \mathrm{O}\right)_{5}\right]^{2+}+\mathrm{H}^{+}$, the $\mathrm{pH}$ of amino acid chromium complex solutions drops during the heating processes as a result of hydrolysis and coordination reaction with temperature rising and time increasing. The molecular thermal motion could result in the carboxyl group of amino acid dissociation which makes $\mathrm{H}^{+}$release.
The dissociated amino acid carboxyl group enters the inner of the complex to coordinate with the chromium ion, which causes less dissociated amino acid to exist and more amino acid carboxyl groups to dissociate in solution. The processes are promoted by microwave irradiation and water bath, but microwave leads to more significant change. Because the polar amino acids molecules and chromium complex are affected by the microwave directly to generate more collision and rotation at the same temperature compared with water bath heating, the reaction rate is accelerated just microwave could make other chemical reactions much faster.

\section{CONCLUSIONS}

In the study, microwave irradiation was used to heat the reaction between chromium complex and four kinds of characteristic amino acids for studying the influence of microwave on its stability and reaction rate, and water bath heating was used as control. The results showed the coordination reaction between chromium 
complex and amino acid was accelerated and the stability of the complex was enhanced after heating, but microwave irradiation results in faster reaction rate and better stability beyond thermal. Moreover, microwave had stronger effect on improving the reaction between chromium complex and amino acid when the polarity of amino acid was large just the influence tendency of the reaction from large to small is aspartic acid > hydroxyproline > lysine > glycine. This study would provide some hints for understanding how microwave affects chrome tanning and might be useful to apply microwave in tanning in future.

\section{Acknowledgement}

The authors wish to thank the National Natural Science Foundation of China (No. 21576171) for financial support.

\section{REFFERENCES}

1. Adam, D., Microwave chemistry: Out of the kitchen, Nature, 2003, 421, 571-572, https:// doi.org/10.1038/421571a.

2. Diaz-Ortiz, A., Prieto, P., de la Hoz, A., A critical overview on the effect of microwave irradiation in organic synthesis, Chem Rec, 2019, 19, 85-97, https://doi.org/10.1002/ tcr.201800059.

3. Asomaning, J., Haupt, S., Chae, M. et al., Recent developments in microwave-assisted thermal conversion of biomass for fuels and chemicals, Renew Sustain Energy Rev, 2018, 92, 642-657, https://doi.org/10.1016/j. rser.2018.04.084.

4. Pandya, A., Sutariya, P.G., Menon, S.K., Protein mediated synthesis of gold nanobiocatalyst by microwave: A high efficient catalytic activity for the selective oxidation of benzyl alcohol, $J$ Mol Catal A-Chem, 2013, 380, 78-83, https:// doi.org/10.1016/j.molcata.2013.08.022.

5. Ahirwar, R., Tanwar, S., Bora, U. et al., Microwave non-thermal effect reduces ELISA timing to less than 5 minutes, RSC Adv, 2016, 6, 20850-20857, https://doi.org/10.1039/ C5RA27261K.

6. Wang, H., Chen, W.Y., Gong, Y. et al., Based on the studies of chrome tanning chemistry with microwave, Leather Science and Engineering, 2011, 21, 5-9.

7. Zhang, J.W., Chen, W.Y., Gaidau, C., Microwave irradiation: an innovative routine to promote goat skin chrome tanning process, J Am Leather Chem Assoc, 2019, 114, 287-292.

8. Liu, Y., Zhang, J.W., Chen, W.Y. et al., Microwaveirradiated tanning reaction of aluminum with collagen, J Appl Polym Sci, 2019, 4868248691, https://doi.org/10.1002/app.48682.

9. Wu, J.C., Fan, Z.W., Zhang, J.W. et al., Impact of microwave irradiation on vegetable tanning, J Soc Leather Technol Chem, 2018, 102, 7-11.

10. Fang, Y.T., Zhang, J.W., Ning, G.Q. et al., Effects of microwave irradiation on hydrolysis of zirconium sulfate and thermal stability of zirconium tanned powder, Leather Science and Engineering, 2017, 27, 12-16.

11. Gong, Y., Cheng, K., Zhang, T. et al., Automated clear leather dyeing assisted by wringing, ultrasound and microwave, J Am Leather Chem Assoc, 2011, 106, 127-132.

12. Zhang, J.W., Zhang, C.L., Wu, J.C. et al., Advantages of utilizing microwave in soft leather drying, Leather and Footwear Journal, 2017, 17, 2, 81-86, https://doi.org/10.24264/ Ifj.17.2.1.

13. Zhang, J.W., Zhang, C.L., Wu, J.C. et al., The influence of microwave non-thermal effect on leather properties in drying, I Am Leather Chem Assoc, 2017, 112, 135-139.

14. Gong, Y., Zhang, T., Chen, W.Y., Behavior of fatliquored leathers in a microwave field, $J$ Am Leather Chem Assoc, 2012, 107, 60-67.

15. Zhang, J.W., Wu, J.C., Chen, W.Y., Special review paper: Applications of microwave in leather field: Further research for leather chemists and technologists, J Am Leather Chem Assoc, 2017, 112, 311-318.

16. Zhang, J.W., Cao, N., Zhou, N. et al., Hydrolysis and olation of chromium sulphate under microwave irradiation, I Soc Leather Technol Chem, 2017, 101, 1-5.

17. Cao, N., Zhang, J.W., Wang, S.J. et al., Behaviors of chromium nitrate hydrolysis and olation under microwave irradiation, Leather Science and Engineering, 2016, 26, 5-9. 
18. Chen, J., Li, X.Z., Wang, Z.W. et al., Microwave irradiation assisted the stability constant of chromium(III) Complexes, Leather Science and Engineering, 2019, 29, 24-29.

19. Chen, J., Zhang, J.W., Zhou, N. et al., Influence of microwave irradiation on the stability of chromium (III) complexes, Leather Science and Engineering, 2017, 27, 5-9.

20. Wu, J.C., Liao, W., Zhang, J.W. et al., Thermal behavior of collagen crosslinked with tannic acid under microwave heating, J Therm Anal Calorim, 2019, 135, 2329-2335, https://doi. org/10.1007/s10973-018-7341-5.

21. Wu, J.C., Liao, W., Zhang, J.W. et al., Microwave assisted reaction of gelatin with tannic acid non thermal effect on the crosslinking process, Chem Eng Commun, 2019, 206, 1152-1158, https://doi.org/10.10 80/00986445.2018.1550394.
22. Wang, J.Y., Biochemistry, 2008, Higher Education Press, Beijing.

23. Guan, Z.M., Physical Chemistry, 2010, China Environmental Science Press, Beijing.

24. Chen, W.Y., Li, G.Y., Tanning Chemistry (the fourth edition), 2018, China Light Industry Press, Beijing.

(C) 2020 by the author(s). Published by INCDTPICPI, Bucharest, RO. This is an open access article distributed under the terms and conditions of the Creative Commons Attribution license (http:// creativecommons.org/licenses/by/4.0/). 